\title{
The Culture of Sound: A Case Study of Birdsong Competition in Chana District, Thailand
}

\author{
Aphichet Kirichot ${ }^{1}$, Sopee Untaya ${ }^{1} \&$ Supachai Singyabuth ${ }^{1}$ \\ ${ }^{1}$ Department of Tai Studies, Faculty of Humanities and Social Studies, Mahasarakham University, Khamriang \\ Sub-District, Kantarawichai District, Maha Sarakham Province, Thailand \\ Correspondence: Aphichet Kirichot, Department of Tai Studies, Faculty of Humanities and Social Studies, \\ Mahasarakham University, Khamriang Sub-District, Kantarawichai District, Maha Sarakham Province 44150, \\ Thailand. Email: akirichot138@gmail.com
}

\author{
Received: June 9, 2014 Accepted: July 1, 2014 Online Published: September 22, 2014 \\ doi:10.5539/ach.v7n1p5 URL: http://dx.doi.org/10.5539/ach.v7n1p5
}

\begin{abstract}
Southeast Asian birdsong competitions are vital to the makeup of the Southern Thai economy. This is a qualitative research that uses observation, interview and document study to examine the zebra dove culture of Chana District in Songkhla Province. The research results show that vocal zebra dove competitions stimulate and drive the economy and society of Chana District. Zebra dove breeding is a large and lucrative occupation in the area that has spawned a number of supplementary professions, including birdcage production. The success of local breeding has given Chana an international reputation and has been used as a stimulus for political demonstrations. The original spirit of the songbird culture remains as part of a highly developed financial system.
\end{abstract}

Keywords: birdsong, competition, Southern Thailand, culture, society, zebra dove

\section{Introduction}

'Wow...Ta...Ta...Ta...Kong.' This is the call of the zebra dove, an economically, socially and politically valuable bird to the people of Southern Thailand. Dove-cooing contests are popular in Southeast Asian communities, such as those of Thailand, Malaysia, Singapore, Indonesia and Brunei (Anderson, 2005). The birds are taken to competition fields, raised high in cages on poles and judged on the quality of their singing voices (Wannaprasert, 1985). The champion birds and their trainers are awarded with 'great prestige and unlimited bragging rights' (Stephens, 2000). Yet, the birds have a higher value and deeper meaning for people in local communities.

Chana District is located in Songkhla Province (Rahimmula, 2010; Chana District Research Office, 1992; Songmueang, 1986). On a visit to Chana District, the research team could not help but hear the melodies of the zebra dove from almost every window of every household. Clearly zebra doves were an integral part of everyday life. This article is the culmination of a three-year investigation to discover how and why.

\section{Literature Review}

Vocal dove breeding and competing is relatively unknown outside Southeast Asia. As such, English-language scholarship on the subject is sparse. Wanni Wibulswasdi Anderson (2005) wrote an insightful and revealing piece on the social meaning of dove-cooing contests in Southern Thailand. Anderson's work builds on the foundations of Thai scholars, who have documented the history of dove-raising in Siam and beyond from as early as the twelfth century (Anderson, 2005; Sukpala, 1995; Wannaprasert, 1985). Competitions are a comparatively recent development of the last forty years (Anderson, 2005). Anderson identifies a deeper social significance to birdsong contests in Thailand and argues that there is a strong sense of identity, responsibility and passion among mostly male dove fanciers. This attitude makes dove breeding much more than a financial mechanism, despite the ability of prize-winning songbirds to sell for high prices in the domestic and international markets.

'The de-emphasis on profit making and the emphasis on providing social benefits as an organizational structure of the contest are, perhaps due to the particular mindset of the men who are attracted to dove-raising...As a personality type, [dove fanciers] tend to be both ascetic and aesthetic. They find contentment and aesthetic pleasure in caring for their birds and listening to their songs.' (Anderson, 2005: 87) 
Anderson's paper is a comparison between Thai dove breeding and the coarser pastime of cockfighting. Clifford Geertz documented the cultural symbolism and meaning of the Balinese cockfight in his groundbreaking anthropological publication The Interpretation of Cultures (Geertz, 1973). Geertz showed how 'cocks are symbolic expressions of manifestations of their owners self, the narcissistic male ego writ out in Aesopian terms' (Geertz, 1993: 419). While Anderson states that there is something altogether more subtle and refined about the Thai dove fancier, the symbolism remains. So much so that the "dove-cooing contest is a "deeper play" (Anderson, 2005: 90). It must be noted is that neither Geertz nor Anderson examines the symbolism of their pastimes for women, leaving their analyses somewhat androcentric.

In fact, following the definition by The SportAccord Council (n. d.), cockfighting may not be directly compared to dove-cooing as a sport due to the harm it causes the fighting birds. Although there are many examples of animals used in human sport, perhaps only one shares its characteristics with Thai dove-cooing (Gillett \& Gilbert, 2014). Vinkensport, vinkenzetting or finch-sitting, is a Flemish finch singing competition that dates back to 1596 (Bilefsky, 2007). The mechanisms of the sport are less complex than the Thai dove-singing scoring system, yet competition is just as fierce, winners just as prepared and prizes just as prestigious (Anderson, 2005; Bilefsky, 2007). Birds can even be disqualified from competition for making the wrong sound or chirping in the wrong 'dialect' (Bilefsky, 2007; Liberman, 2007). Thomas Hardy wrote his poem 'The Blinded Bird' as a protest against the ruthless vinkenier tradition of blinding the finches with hot needles to remove distractions from their singing duties (Hardy, 1916). The blinding practice was banned in 1920 thanks to a campaign headed by blind World War One veterans (Cordon, 2013). More recently there has been a backlash by bird protection group Vogelbescherming Vlaanderen against the listing of vinkensport on the register of Flemish cultural heritage (Flanders Today, 2013). The Flemish sport has come under more scrutiny than its Southeast Asian cousin among animal rights groups, perhaps due to the limited implementation and scope of animal welfare laws in Asia (Rahman, Walker \& Ricketts, 2005).

The opposition to vinkensport and the social significance of Anderson's dove-cooing and Geertz's cockfighting allude to greater value and meaning of birds in society. The relationship between birds and people over time has been well documented, most recently by Mark Cocker (2013; Zickefoose, 2013). Perhaps one of the strongest relationships, physically and mentally, is the human and the parrot. Parrot-raising is coincidentally identified by Anderson as a growing Southern Thai pastime (Anderson, 2005). There has been continuous use of birds by humans throughout history, from feather decoration in Papua New Guinean tribal headdresses to goldfinch depictions in Renaissance art (Collar, Long, Gil, \& Rojo 2007; Diamond, 1986; Friedmann, 1946). This relationship, or possibly exploitation, continues in the realm of songbird sport.

\section{Methodology}

This is a qualitative anthropological investigation with three primary aims: 1) to summarize the zebra dove breeding culture in Chana District; 2) to analyse the meaning and value of zebra doves for the local community in Chana District; 3 ) to assess the influence of zebra dove birdsong in the local economy, society and politics. Field study was conducted in Chana District, Songkhla Province and at competition sites. Three communities in Chana District were purposively selected for the investigation: Surao, Ban Na and Ban Talingchan. These communities were selected based on the criteria that they were multicultural, all households raised zebra doves and there was a range of economic statuses. The research population was made up of Chana residents and visitors. Residents were key informants for the study and were divided into three groups: Thai-Buddhist, Thai-Muslim and Thai-Chinese. The key informant group was made up of breeders, farm owners, zebra dove club members, birdcage manufacturers, birdfeed manufacturers and politicians.

Three principal research methods were used for data collection: observation, interview and document study. Both non-participant and participant observation techniques were employed to assess the local geography and characteristics of the community, including the lifestyle of the three primary ethnic groups, zebra dove breeding, birdsong competitions, training and community activities. During observation, the research team was particularly interested in the relationship of the three ethnic groups and external visitors. For the participatory element of the investigation, the research team took part in family breeding activities including training, competition and sale of birds. Structured interviews and informal conversations enabled collection of primary data directly from key informants. Documentary research of literature related to the history and politics of the region and the culture of zebra dove breeding added weight and context to the primary evidence. Three tools were used for data collection: an interview form, an observation form and a form for recording audio-visual data. There were two types of interview, one for key informants and the other for external visitors, which differed in the depth of questioning. Key informants were asked for deeper meaning, opinions and facts than the external visitors. The interviews were conducted in four parts. The first part asked for respondent personal information. Parts two, three and four 
were conducted in line with the three aims of the research: the zebra dove breeding culture in Chana District, the meaning and value of zebra doves for the local community and the influence of zebra dove birdsong in the local economy, society and politics. Data was analysed descriptively by categorising the findings into three groups, according to the aims of the research. This investigation was conducted from 2009 to 2012.

\section{Results and Discussion}

\subsection{The Zebra Doves of Chana District}

The sound of the zebra dove carries a special meaning in all corners of Chana society. The birds were first captured from the forest by trapping, beating and baiting (Figure 1). The birds were kept as pets to add to the ambience of the home with their call and as symbols of good luck and prosperity (Hassan Niyomdecha, personal communication, 2011). The birds were then used by local businesses, such as tea houses, to provide a pleasant atmosphere and background noise for their customers. Although there had been small local contests throughout history, the first organized birdsong competition in Chana was in 1977 (Kan Kongthong, a local villager, personal communication, 2011). From the humble beginnings of small village gatherings, the birdsong competitions are now staged at an international level. The development of competitions sparked the phenomenon of zebra dove breeding at homes and on farms, which significantly altered the local lifestyle, economy and the importance of the zebra dove to the community (Teerapong Donsri, personal communication, 2010). The zebra dove is important to Chana beliefs, economy and society.

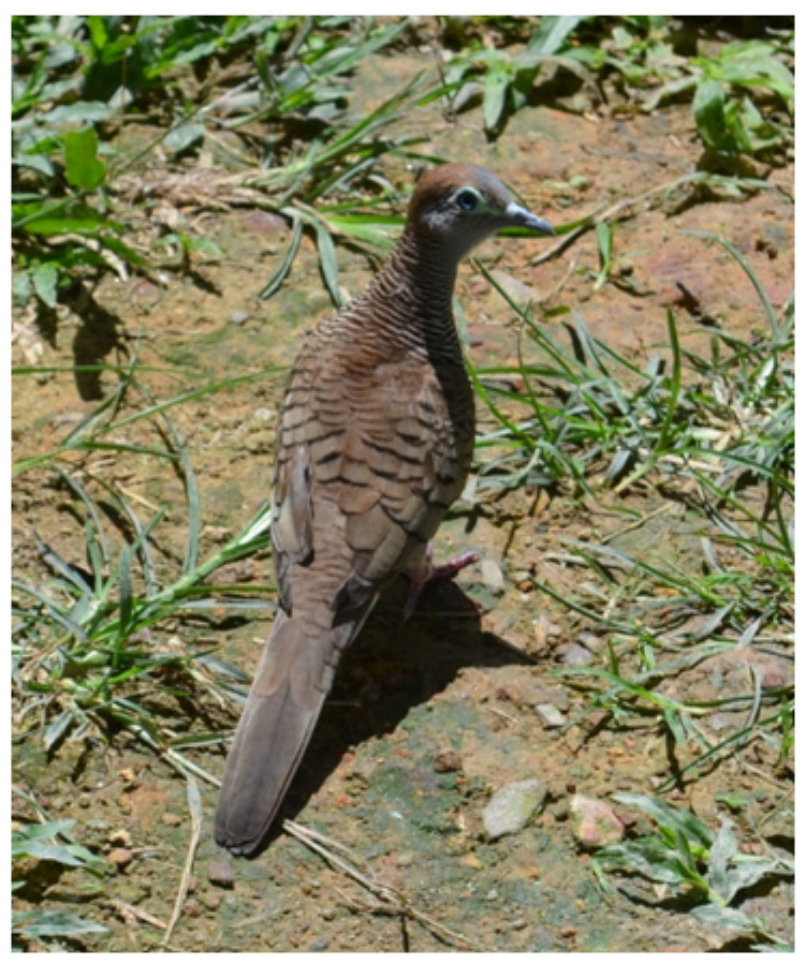

Figure 1. A wild zebra dove

In order to better understand the mechanics of the birdsong competitions, the research team observed the vocal zebra dove contest for the Prince Vajiralongkorn Cup on $27^{\text {th }}$ February 2011. The competition was organised and sponsored by local institutions and held at Wungdee Field, Talingchan Sub-district, Chana District. The key elements of the competition and its preparation are described in table 1 (Table 1). 
Table 1. Field notes from observation of the Prince Vajiralongkorn Vocal Zebra Dove Contest on $27^{\text {th }}$ February 2011 and its preparation

$\begin{array}{ll}\text { Event } & \text { A meeting was held by the competition committee to plan all aspects of the event. The main point } \\ \text { preparation } & \text { of the meeting was allocation of duties and responsibilities. Public relations were made the job of } \\ \text { the Songkhla Provincial Administrative Organization. As, Arun Bunreuang, the assistant director } \\ \text { of Anuban Songkhla School observed, 'the involvement of the Provincial Administrative } \\ \text { Organisation has generated increased interest from the local community this year because they } \\ \text { have used many different advertisement methods, including leaflets, vinyl posters, radio, } \\ \text { television and internet' (personal communication, 2010). } \\ \text { The competition committee selected Wungdee Field, Talingchan Sub-district, Chana District as } \\ \text { its venue. The area of Wungdee Field is approximately } 40 \text { rai (16 acres), which was deemed } \\ \text { suitable for the competition, parking space, exhibitions and stalls. Despite its logistic suitability, } \\ \text { concerns were raised because the area is home to a large population of local sandpiper birds, } \\ \text { which could scare the zebra doves (Pairot Likitkoson, personal communication, 2010). } \\ \text { Nevertheless, after the initial meeting, the venue was prepared by erecting shelters, creating and } \\ \text { improving roads (Thanat Intornsri, organisation committee member, personal communication, } \\ \text { 2010). Posts were arranged in 50 rows of } 16 \text { for hoisting the birdcages during the competition. The } \\ \text { posts were four-five metres high and were arranged three metres apart in their rows. Each row was } \\ \text { 2.5 metres apart. The competition area was at the southern end of the site and included the } \\ \text { winners' stage, trophy display and convenience area for the committee and judges. }\end{array}$

Bird Although the birds are raised for the purpose of competing, there are extra preparations made in selection the run up to a contest. Birds will be chosen from the age of three months for the quality of their three sounds 'Wow', 'Ta' and 'Kong'. Aside from the rhythm of their calls, breeders will also select birds based on their physical characteristics. 'Birds can be chosen by their appearance from 5 or 6 months onwards. The birds with the best calls have the best feathers. Also we look for birds with a short, thick, high beak and a large, expanded throat. Birds with these characteristics are the most popular because they will make a loud, booming call, which is preferable to a subtle chirp. They're also more expensive!' (Hassan Niyomdecha, personal communication, 2010).

Training 'The birds must be trained, just as a boxer trains for a fight' (Direk Dodasair, personal communication, 2010). There are community practice grounds for breeders to train their birds. Direk Dodasair uses his practice ground in Ban Tawle to 'post' his birds every Tuesday. He, along with other breeders, will test the sounds of his birds and create a scenario to familiarise the birds with competition. It is particularly important to give the birds experience in the sun and in proximity to older birds. Breeders will also practice transporting the birds so that they are not overwhelmed on contest day. There are 3 steps in bird training: 1) opening and closing the cage cover; 2) transporting the birds; 3 ) practice hoisting the birds (Figure 2).

Competition One day before: The organising committee make final preparations and checks.

day

6am: Traders set up their stalls around the competition grounds (Figure 3).

7am: Bird breeders begin to arrive at the grounds and congregate around their respective zones (according to bird sound category).

8am: Entrance fees are paid in return for a competition ticket and breeders set up at their posts (Figure 4).

8.30am: The chairman of the event officially opens the competition at the opening ceremony.

9am: Judges walk around the site assessing the birds and awarding points.

10am: People begin to head for shelter from the sun and refreshments.

10.30am: The car park is full with over three-hundred vehicles.

10.45am: The heat of the sun is intense and the bird calls have quietened, so judges meet to decide the winners. Bird breeders hurry to cover their cages and protect their birds from the sun.

1pm: The results of the competition are announced

After the awards ceremony: Winners and officials are interviewed by the media and photographs are taken. Contestants then make their way home, or to individual celebrations at winners' houses. The grounds are cleared by officials.

The prizes 'The winners' trophies have a really important role in raising social status' (Terdchai Jintana, personal communication, 2010). Particularly important is the reputation of bird breeding ability gained by trophy holders. Trophies are an excellent form of publicity for farms and breeders regarding the quality of their birds. The prizes have extra significance and prestige given their association with Prince Vajiralongkorn. The budget for prizes came from sponsorship by the Chana Power Plant, Trans-Thai-Malaysia (TTM) and Isuzu Chana. This sponsorship was supplemented by funds from bird registration fees. Each entrant was required to pay a fee of 300 baht. There were 922 entrants (Chaiyawut Ledet, personal communication, 2011). Aside from the cups and trophies, there were other prizes, the largest of which was an Isuzu Spark Ex. 


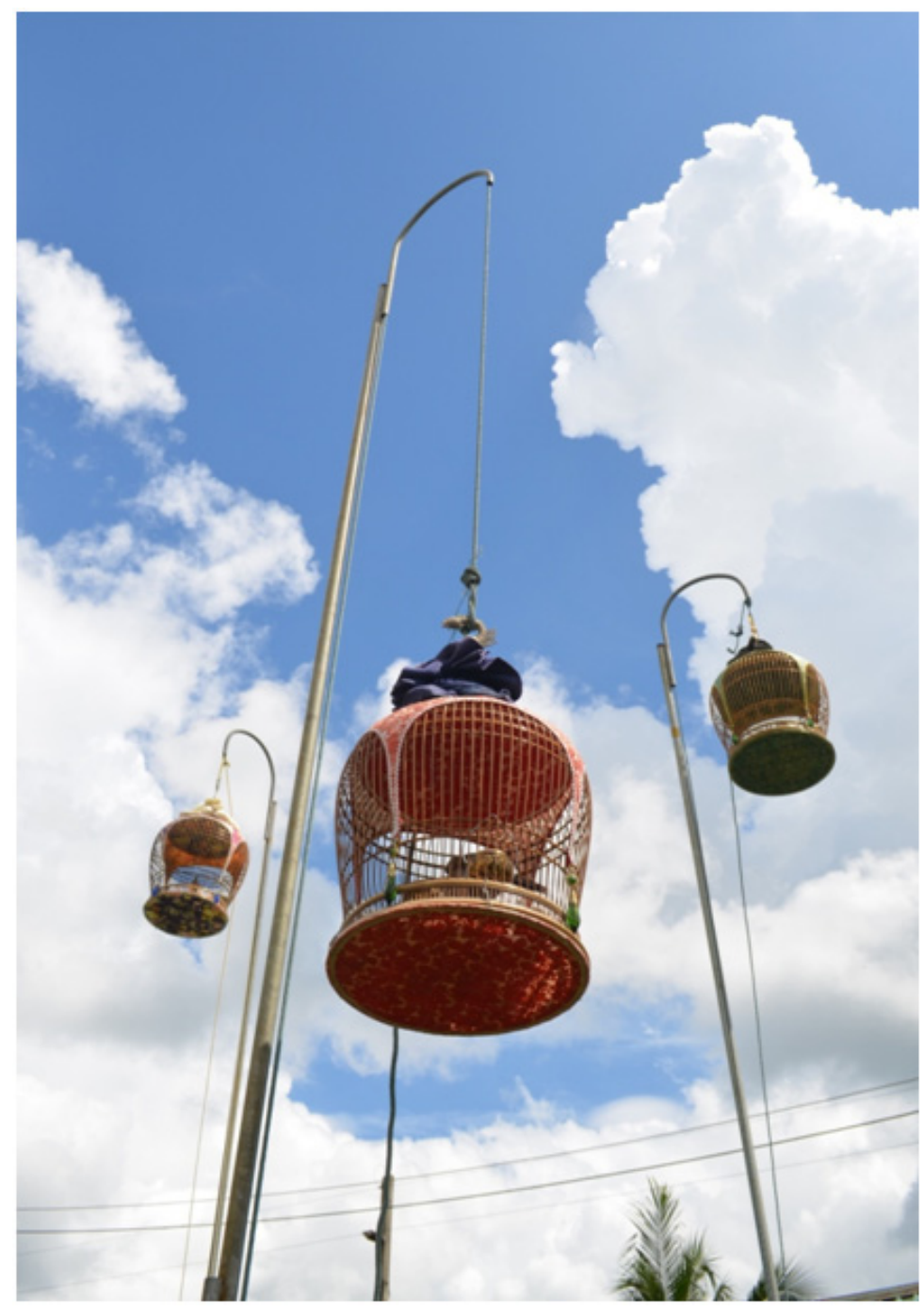

Figure 2. Birds being hoisted into position on their competition posts

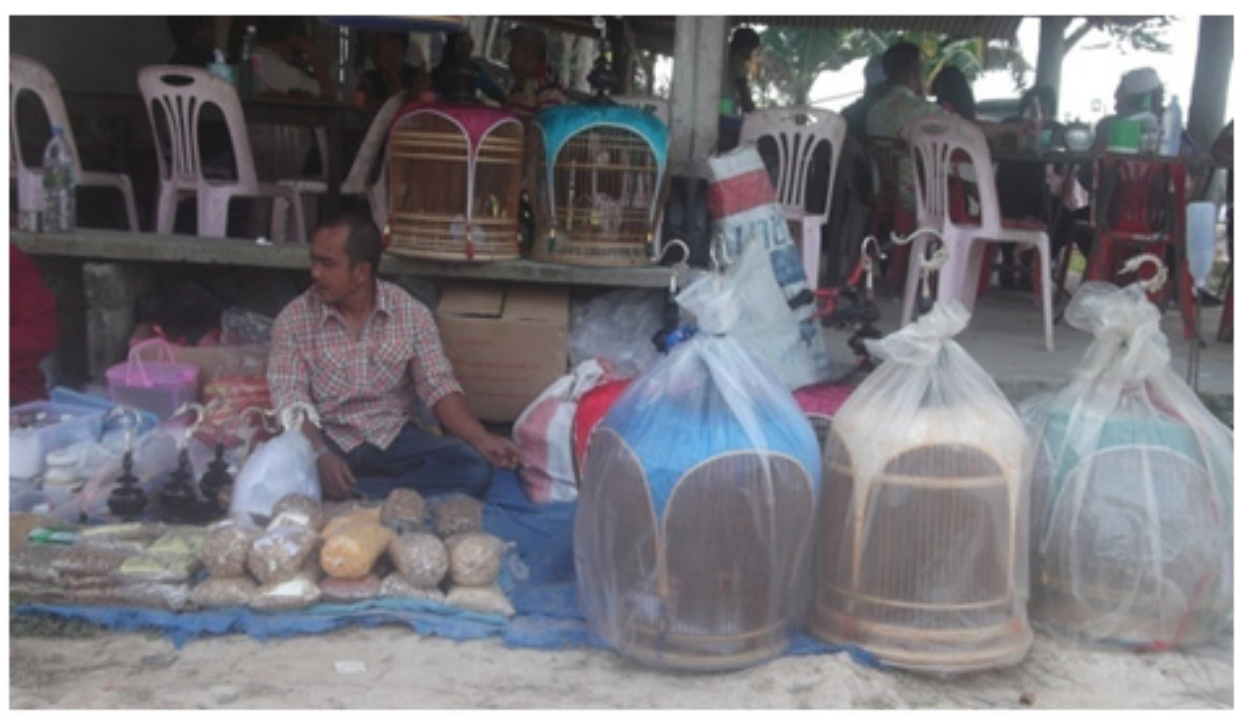

Figure 3. A bird breeding accessory trader selling goods at the dove-cooing competition 


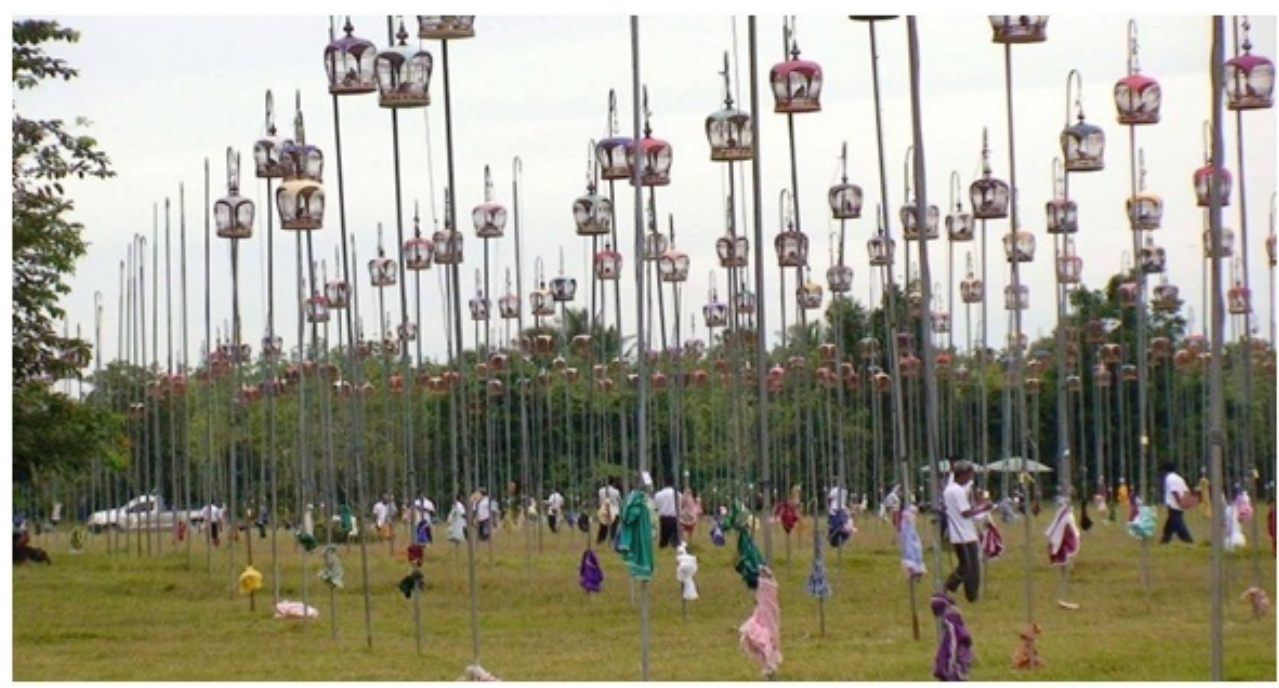

Figure 4. The field of competitors during the dove cooing competition

\subsection{Economies and Philosophies: The Meaning and Value of Zebra Dove Birdsong}

The Chawawong are the people responsible for the birds. This name derives from the Thai name nok-kao-chawa, meaning Java or zebra dove. The culture of the Chawawong revolves around the 'zebra dove economy'. In fact, the trade of competing zebra doves is a lucrative business, with the most melodious doves commanding as much as one-million Thai baht. The highest price paid for a zebra dove was 1,500,000 baht paid for the bird Phetsalatan in 2002. 'The birds are just like singers and are judged on their sound. Just as the most popular singers make the most money, the most melodious birds fetch the highest prices' (Abdulraman Senair, personal communication, 2010). This price is based on the human notion of aesthetics (Singyabut, 2004). The perceived aural beauty of its call and the visual beauty of its cages have increased the aesthetic value of the zebra dove. There are a host of awards for the birds deemed to have the best sound, the most prestigious of which is conferred by the monarchy and entitles the bird to command the highest price in the marketplace. These factors have added to the complexity of the zebra dove culture in Songkhla Province.

The high value of zebra doves in the community has led to the creation of many jobs in Chana, including bird breeding and birdcage production (Hassan Niyomdecha, personal communication, 2010). Modern zebra dove breeding in Chana District is considered a major occupation. There is a dove market, dove funding and analysis of domestic and international dove customers. 'Unlike before, zebra doves are not only sold within the country but also to many of the ASEAN nations, especially Malaysia, Indonesia, Singapore and Brunei' (Direk Dodasair, personal communication, 2011). Mr. Dodasair's comments highlight the transformation of the zebra dove culture to a zebra dove economy since the introduction of competitions.

There are three types zebra dove sales: sale of parent stock, sale of hatchlings, sale of famed prize-winners. Rammalee Sa-A (personal communication, 2011), a local dove breeder, told us that she purchased a male and female couple in October 1994. She paid 50,000 baht for the cock and 40,000 baht for the hen. The two birds have proved a sound investment for Mrs Sa-A, producing over 1,000 offspring and providing a steady income. The hatchlings are sold in one of two categories. Nok-Lo are birds with a nondescript sound that are sold cheaply and often in clutches. Nok-Mee-Radab are graded birds with a distinctive character to their voice, pitch and call. The sale of these birds starts at 1,000 baht. The final type of sale is the sale of famed prize winners. The price of these birds is high and increases with every competitive success because they have already been examined under the scrutiny of a judging committee. One example is the bird Petnarai, owned by Chukiert Tonjaroen. Prior to winning the 1993 Prince's Cup in Songkhla, the bird was valued at 100,000 baht. After the win, the bird was subjected to an unsolicited offer of 300,000 baht, which the owner rejected. Prize winners can be sold for huge sums of money, such as Nokbaeng, owned by Samak Intornsiri, which is valued at 1,000,000 baht, having won the Princess Sirindhorn Cup in 1993-4 and a host of local competitions since. 'The prize birds are either bought by rich enthusiasts who want to listen to them and increase their own prestige and reputation or breeders who want to create the perfect bloodline' (Kan Kongthong, personal communication, 2011). 
There are mixed motives in the world of bird breeding and trading. While some wealthy fanciers are prepared to pay large sums of money to secure the perfect songbird, others see only folly. Owner of L.K.M.O. Farm, Mr. Abdulraman Senair said 'I always ask them [the buyers who intend to keep the birds at home] what they're doing. Why buy a prize-bird for a million baht? It makes no sense. If the bird dies, your money dies with it. You'd be better off buying a rubber farm; at least then you'd see a return.' (Abdulramen Senair, personal communication, 2010). For many people in Chana, zebra doves are 'economy animals' that provide both primary and secondary sources of income (Paisin Kaewmahakan, local school director, personal communication, 2011). The additional occupations driven by the popularity of the zebra dove primarily include food processing and cage making but there are a number of supplementary industries that have emerged from the popularity of zebra dove breeding and competition:

- There are businesses that make bird cage accessories, such as feeding trays, cage heads and perches.

- Meua Peuan are carers for hire. These 'bird-sitters' are usually experts in bird care and handling with no prize-birds of their own. The Muea Peuan offer their services to inexperienced prize-bird owners, who need specialists to prepare and train their songbirds for competition.

- The bird trade has become so big that agents are employed to broker sales.

- The bird cage manufacturers require regular supplies of bamboo, which boosts the local bamboo industry.

- Excess bamboo from cage construction is used to make accessories, such as mobiles.

- The bird breeding and particularly the competitions attract tourists to the region.

Cage production and sale is a large part of the zebra dove economy. 'For zebra doves to be in good condition and have a high price, they must be kept in beautiful cages' (Roman Kreeda-o, personal communication, 2011). 'The best birds should be in the most expensive cages. They can earn up to 10 million baht for their owners so they should live in high quality cages made from the choicest materials (Figure 5)' (Prasit Saeng-nikoon, personal communication, 2011). Given the importance of the cages, a production group has been established with Roman Kreeda-o as its chairman 'to inherit and transmit the traditional knowledge of cage production and ensure the value of zebra dove cages is maintained and developed to the same extent as the birds' (Roman Kreeda-o, personal communication, 2011). The price of the cage is determined by the appeal of the design, the quality of the handiwork and the rarity of the materials, which include precious stones (Paisin Kaewmahakan, personal communication, 2011). Cage prices range from a few hundred baht to over a million baht. The breeders pay close attention to every aspect of the zebra dove environment; even the cage cover is woven from imported fabric from Malaysia and Singapore (Wilaiwan Chotsair, personal communication, 2011). Yet, as the following quote reveals, there is a fine line between the zebra dove economy and the zebra dove philosophy.

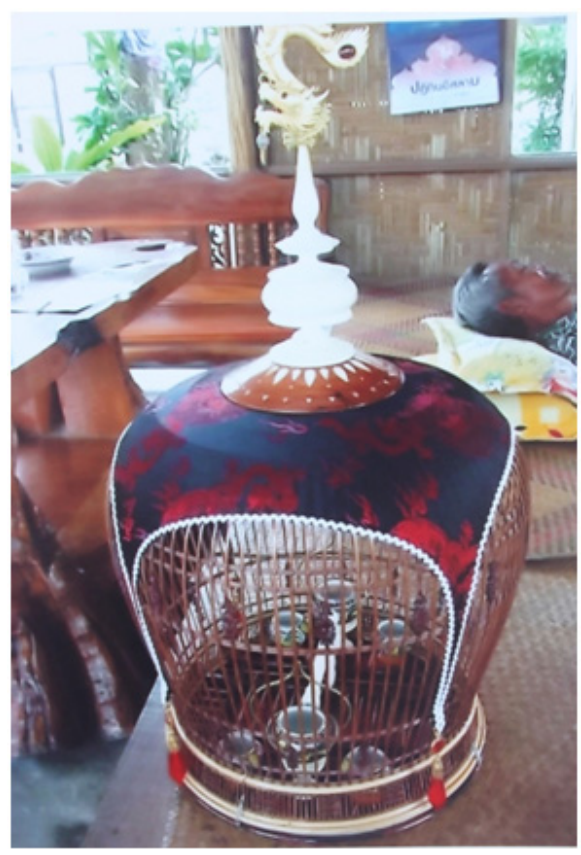

Figure 5. A cage made by Prasit Saeng-nikoon 
This particular cage is made from rare and valuable dalbergia oliveri wood, gold, silver, pearls, ivory and jewels. This cage was commissioned by a wealthy zebra dove trainer and is valued at 1.5 million baht.

'I make my bird cages out of love for the birds and love for my art. Each cage is made by my own hands and I'm always reluctant to sell, even if each one is worth a million baht. I'd rather keep the cages and put them on show. But the people buying my products, whether they're from Thailand, Malaysia, Indonesia, Singapore or Brunei, all love their zebra doves. For this reason, I agree to sell' (Prasit Saeng-nikoon, personal communication, 2010).

According to respondents, there are four reasons for the success of the Chana dove economy: 1) breeders are dedicated to their birds; raising birds is an integral part of life, not just an occupation; 2) it is a breeding community, where mutual assistance and advice is shared; 3) there is a vibrant tea-drinking culture that promotes the exchange of breeding knowledge and conversation; 4) the breeders have high levels of honesty and integrity. Not only do the Chawawong pursue their passion and livelihood, they have also built the reputation of Chana District and Thailand in the international community, which attracts tourism to Songkhla Province (Direk Dodasair, personal communication, 2012). Such is the esteem of the Chawawong that the head of 'the Indonesian Department of Livestock Development visited Songkhla to observe the practices of the local breeders' (Arun Bunreuang, personal communication, 2012). The Indonesian delegation visited in August 2012 (Direk Dodasair, personal communication, 2012).

\subsection{The Politics of Sound}

The politics of sound is the use of birdsong as a legitimate factor and tool in combating physical crises. The call of the zebra dove has an influence beyond the competition grounds because it is used in garnering support and momentum for politically motivated demonstrations among the electorate.

The seventh national development plan for Thai economy and society highlighted the importance of international economic cooperation (Office of the National Economic and Social Development Board, 1992). With a policy of developing domestic industry through international collaboration, the Indonesia-Malaysia-Thailand Growth Triangle (IMT-GT) was established in 1993. This was heralded as 'a subregional cooperation initiative formed...by the governments of Indonesia, Malaysia, and Thailand to accelerate economic transformation in less developed provinces' (Centre for IMT-GT Subregional Cooperation, n.d.). The southern tip of Thailand was made a focal point of the economic triangle, which led to the construction of a gas separation plant in the region, the Thai-Malaysia gas line and increased electrical capacity in Southern Thailand. The aim of these developments was to boost the economy in the five southern provinces of Satun, Pattani, Yala, Narathiwat and Songkhla (Banjong Chuaichoo, Chana Chief District Officer, personal communication, 2010). However, the policy altered the physical environment of Chana due to the construction of the Chana Power Plant (Figure 6).

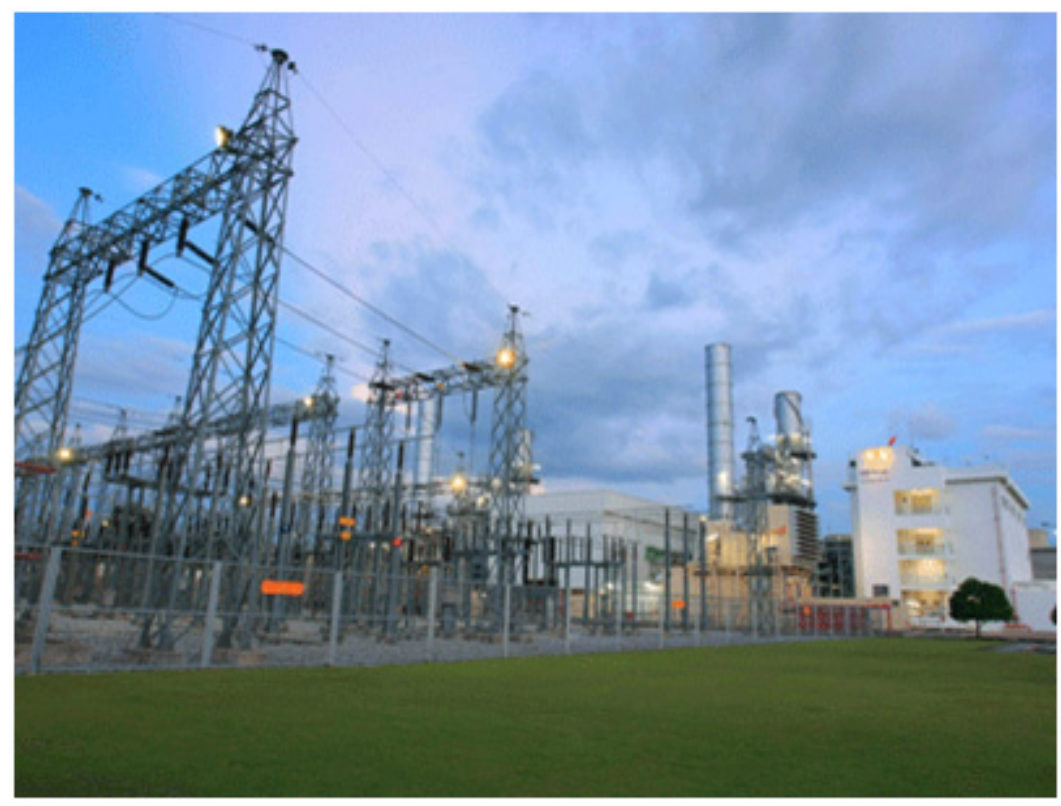

Figure 6. Chana power plant 
'The government policy caused grave problems for the people and environment of Chana District. The two plants contributed to increased pollution in Chana, rising local temperatures, destruction of wildlife and disruption to local communities, especially the public space of the Muslim community. Moreover, the pollution generated from the plants affected the health of the zebra doves and led the quality of their calls and coos to decrease.' (Sommai Kwantongyim, a senior member of the Chawawong community opposing the Chana Electrical Power Plant and Gas Separation Plant, personal communication, 2010).

Local people believe that the IMT-GT caused widespread environmental changes in and around Chana. This local market trader (Figure 7) said that the big sea fish and shrimp had disappeared since the power plants had been constructed (Anonymous, personal communication, 2010). This observation was confirmed by Kan Kongthong: 'marine and freshwater animals, such as shrimps, shellfish, crabs and fish, all died. There was also noise pollution and the temperature was unusually warm' (personal communication, 2010). Abdulraman Senair (personal communication, 2010), who lives close to the gas separation plant in Ban Talingchan, told how residents were reluctant to eat locally cultivated produce, which grew deformed and diseased. The construction and operation of the two plants had, at the very least, a perceived affect on the people, their environment and their birds.

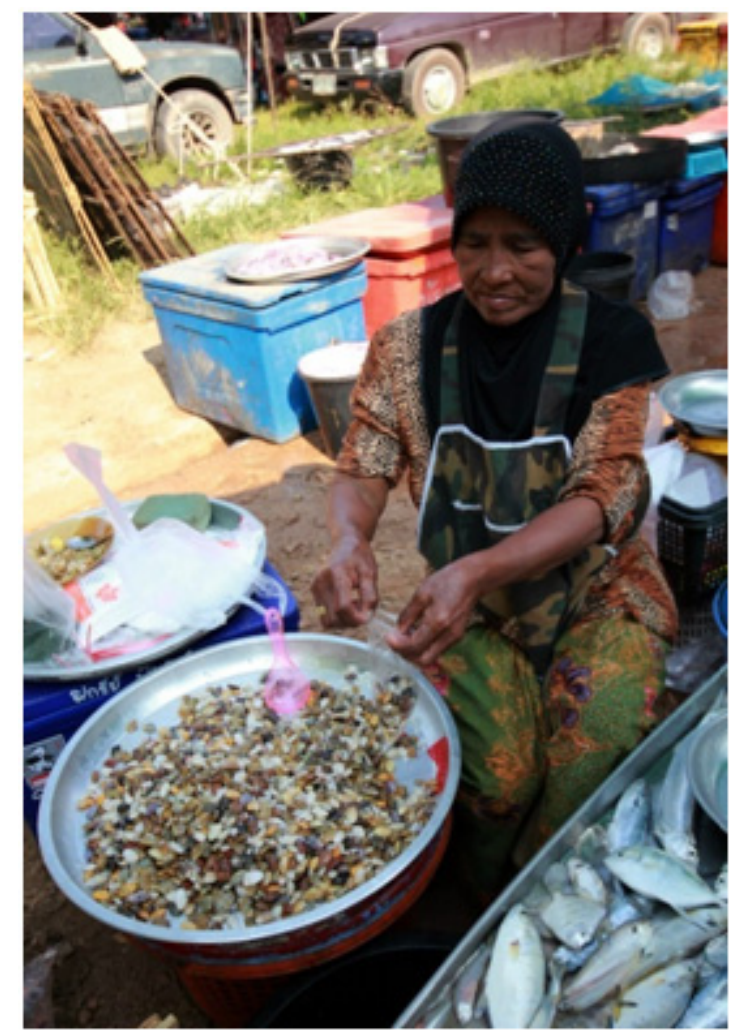

Figure 7. A local market trader commenting on the effects of the Chana Power Plant

\footnotetext{
'The call of the zebra dove is a fragile thing. The quality of their sound is affected by chillies and mosquito spray, so just imagine how much it deteriorates with factory smoke, fumes and construction waste. The temperature, water quality and noise levels all influence the bird calls. If their sound quality is low, their value depreciates. We're left with birds worth no more than 100 baht. This is why we added our voices to the protests' (Adun Jema, personal communication, 2010)

The conflict that these issues caused (Figure 8) between the local people of all ethnic backgrounds and the government institutions and power plants was a social crisis (Euwattananukul, 2006). Given the high concentration of bird breeders in the community, the Chawawong were a large part of the protest movement and were considered as their own entity during the negotiations for compromise. A solution to the crisis was only found when the power plants considered birdsong as an element of their negotiation with locals. The plants pledged sponsorship of 1.5 million baht per year to the Chawawong, which they used to launch an international zebra dove festival. The inaugural festival was held from the $30^{\text {th }}$ to the $31^{\text {st }}$ August 2008 and has been annually repeated until today.
} 


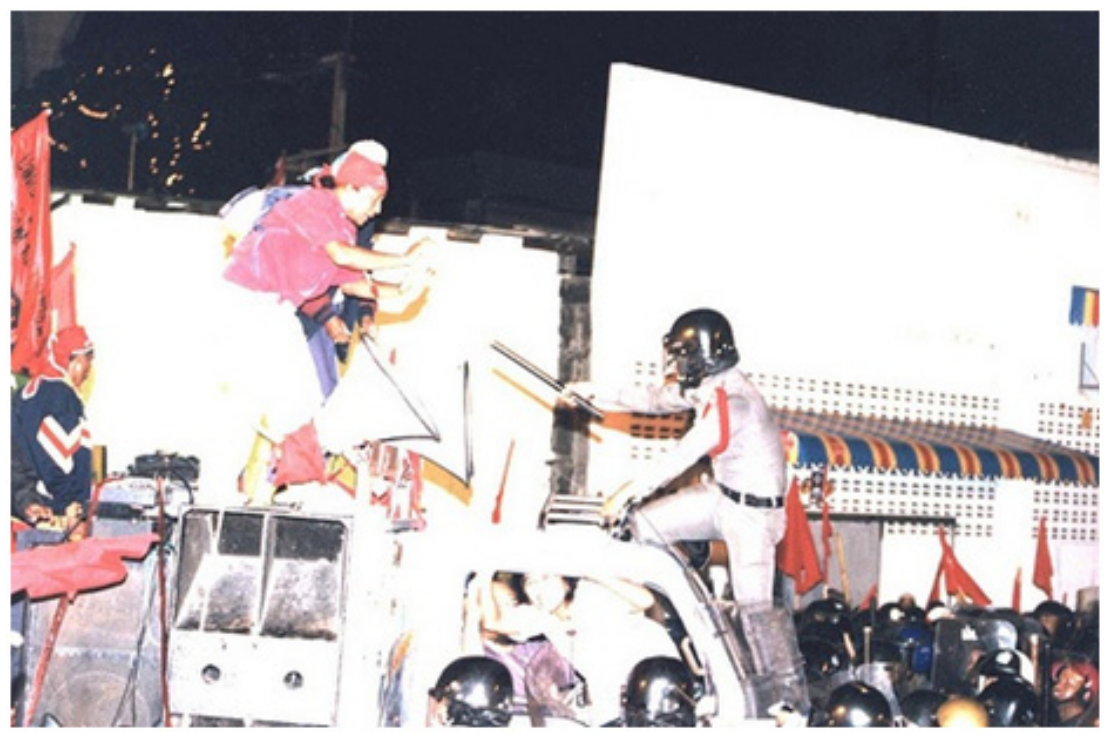

Figure 8. Confrontation between local protestors and police regarding the development of Chana Power Plant and its effect on the environment

\section{Conclusion}

The birdsong of zebra doves is a natural phenomenon that has been transformed into a social pleasure through use as an artistic component of everyday life (Singyabut, 2004). The culture of bird breeding in Chana District grew from the practice of capturing zebra doves as pets. Over time this has evolved into the competition culture and bird economy of the Chawawong of Songkhla. Although dove-cooing sport is not monetized through gambling in the same way as other sports, it is such a vital part of the local economy that it must be considered a financial operation. In 2005, Anderson made the following observation:

'It appears that the increasing temptation of profit-making through economic transnationalism, the high-price trading of champion dove across national borders, has become a new challenge and threat to the spirit of dove-raising and dove-cooing contests as originally conceived and nourished by dove fanciers.' (Anderson, 2005: 90)

Although Geertz's 'deep play' (Geertz, 1973) and Anderson's (2005) 'deeper play' for the dove fancier remain, the Chana dove economy has evolved. The specific appearance of dove agents, birdcage accessories and dove-sitters indicate a highly developed financial system. Moreover, Chana's international reputation in the dove-breeding community indicates the success of its domestic market. The events of the power plant crisis show that 'the spirit of dove-raising' remains, but it would seem that the spirit now has a price.

\section{Acknowledgments}

This paper is part of the $\mathrm{PhD}$ thesis entitled 'Politics of voice in the process of cultural pluralism: A case study of Zebra Doves of Chana Community, Songkhla Province' by Aphichet Kirichot. The PhD advisors were Dr. Sopee Untaya and Associate Professor Dr. Supachai Singyabuth. The investigation was conducted as part of the Tai Studies doctoral program in the Faculty of Humanities and Social Studies, Mahasarakham University.

\section{References}

Anderson, W. W. (2005). Beyond the cockfight: Masculinity and the Thai dove-cooing contest. Manusya: Journal of Humanities, 9, 80-91.

Bilefsky, D. (2007). One-Ounce Belgian Idols Vie for Most Tweets Per Hour. Waregem Journal. Retrieved from http://www.nytimes.com/2007/05/21/world/europe/21 finch.html?_r=0

Centre for IMT-GT Subregional Cooperation. (n.d.). Indonesia-Malaysia-Thailand Growth Triangle. Retrieved from http://www.imtgt.org/

Chana District Research Office. (1992). Local history of Chana, Songkhla Province [in Thai]. Songkhla: Chana District Research Office. 
Collar, N. J., Long, A. J., Robles Gil, P., \& Rojo, J. (2007). Birds and people: bonds in a timeless journey. Mexico City: CEMEX.

Cordon, G. (2013). The goldfinch: symbol of salvation yet thrice-cursed, 'enjailed in pitiless wire'. Retrieved from http://gerryco23.wordpress.com/2013/10/19/the-goldfinch-symbol-of-salvation-yet-thrice-cursed-enjailed-i n-pitiless-wire/

Diamond, A. W. (1986). A global view of cultural and economic uses of birds. In A. W. Diamond, \& F. L. Filion (Eds.), The value of birds, (pp. 99-109). Cambridge, UK: International Council for Bird Preservation (Techn. Publ. 6).

Euwattananukul, B. (2006, 2 Jun). Series of events in the suppression of the gas plant protest movement...culpable government must compensate [in Thai]. Prachatai. Retrieved from http://prachatai.com/node/8577/talk

Flanders Today. (2013, 17 July). Finch-singing contests recognised as cultural heritage. Retrieved from http://www.flanderstoday.eu/current-affairs/finch-singing-contests-recognised-cultural-heritage

Friedmann, H. (1946). The symbolic goldfinch: its history and significance in European devotional art. Washington, DC: Pantheon Books.

Geertz, C. (1973). Deep Play: Notes on the Balinese Cockfight. In C. Geertz (Ed.), The interpretation of cultures (pp. 412-453). New York: Basic Books.

Gillett, J., \& Gilbert, M. (Eds.) (2014). Sport, animals and society. Abingdon: Routledge.

Hardy, T. (1916). The blinded bird. Retrieved from http://www.online-literature.com/hardy/moments-of -vision/24/

Liberman, M (2007). Dialect variation in the terminal flourishes of Flemish chaffinches. Retrieved from http://itre.cis.upenn.edu/ myl/languagelog/archives/004526.html

Office of the National Economic and Social Development Board (1992). The seventh national economic and social development plan: 1992-1996 [in Thai]. Retrieved from http://www.nesdb.go.th /Default.aspx?tabid $=89$

Pongpaiboon, S (1986). Local sports of the Southern region. In Encyclopaedia of Southern culture, 1986, book 1 [in Thai]. Songkhla: Taksin Institute of Legal Studies.

Rahimmula, P (2010). Muslims in the South [in Thai]. Bangkok: The Press

Rahman, S. A., Walker, L., \& Ricketts, W. (2005). Global perspectives on animal welfare: Asia, the Far East, and Oceania. Revue scientifique et technique (International Office of Epizootics), 24(2), 597-610.

Singyabuth, S. (2004). Philosophy of aesthetics [in Thai]. Teaching documents, Mahasarakham University, Maha Sarakham, Thailand.

Songmueang, S. (1986). Chana. Encyclopaedia of Southern culture,1986, book 2 [in Thai]. Songkhla: Taksin Institute of Legal Studies.

Stephens, J. (2000). No place for cheap trills: Inside the costly world of songbird breeding. Asiaweek 29 (24). Retrieved from http://www-cgi.cnn.com/ASIANOW/asiaweek/magazine/2000/0623/as.society.html

Sukpala, J (1995). Zebra dove breeding and its related culture: A study of Chana District, Songkhla Province [in Thai]. Unpublished doctoral research, Prince of Songkla University, Thailand.

The SportAccord Council. (n. d.). The definition of sport. Retrieved from http://www.sportaccord.com /en/members/definition-of-sport/

Wannaprasert, P. (1985). Tactical training and taking care of Merbok [in Thai]. Bangkok: Buraphasan

Zickefoose, J. (2013). Book Review - 'Birds \& People' by Mark Cocker: A vivid map of the trails birds in 39 countries blaze through people's lives. The Wall Street Journal. Retrieved from http://online.wsj.com/news/articles/SB10001424052702304073204579171591325643478

\section{Copyrights}

Copyright for this article is retained by the author(s), with first publication rights granted to the journal.

This is an open-access article distributed under the terms and conditions of the Creative Commons Attribution license (http://creativecommons.org/licenses/by/3.0/). 